\title{
La Historia de la Literatura Argentina de Ricardo Rojas
}

r. Quienes en $x_{912}$ iniciábamos estudios universitarios en Buenos Aires conocíamos de lejos o de cerca a Ricardo Rojas y habíamos leído varios de sus trabajos: La Nación los acogía. Y como esos primeros decenios del siglo heredaban del precedente la consideración que, difusamente y sin demasiados compromisos, se tributaba al "intelectual" -aunque el intelectual malviviera si fiaba sólo en su pluma-, sentíamos admiración por cuantos daban lustre de cultura a nuestra Argentina agropecuaria. Entre ellos, por Rojas, entonces treintenario.

Los más renombrados escritores jóvenes, ya de precoz madurez en sus inclinaciones poligráficas, llamábanse Leopoldo Lugones, José Ingenieros, Ricardo Rojas. Otros de sus coetáneos eran únicamente escritores o únicamente hombres de acción que, cuando más, cultivaban la oratoria con vistas a la política. En cambio, Lugones, Ingenieros y Rojas removían ideas a la manera de Roberto J. Payró, Juan B. Justo, Alberto Ghiraldo o, luego, Mario Bravo. El afín de aquéllos era y es, en el Uruguay, Emilio Frugoni, escritor y político. $\mathrm{Y}$ así ocurría durante los decenios primiseculares porque en esta zona rioplatense se solían entreverar las idcologías de avanzada - socialismo y anarquismo- con los nuevos moldes que el modernismo fraguaba en el verso y la prosa de América. Darío, herrero máximo residente en Buenos Aires del 93 al 98, había llevado el idioma al más alto grado de maleabilidad para la orfebrería de verso y prosa. El año antes de embarcarse hacia España presagiaba, en su artículo "Un poeta socialista", la triunfal carrera de Lugones. $\mathrm{Y}$ éste, voluble y proteico, empuñaba a poco el cetro de la lírica platense, que quizá pudo ocasionalmente disputarle su cofrade montevideano Julio Herrera y Reissig. Desde los feudos vecinos de la ciencia o de las ciencias - neuropsiquiatría, psico- 
logía, criminología - llegaba Ingenieros a la heredad de las letras con su Psicopatología en el arte, título requerido a Enrique Ferri, y con sus crónicas y notas de viajero: El impuesto del mar, La morfina de Espiaña, Las manos de Eleonora Duse, etc. Y no tardaría en invadir otros feudos vecinos, siempre con gran acopio de regimentadas lecturas y siempre con rauda facilidad especulativa. Lugones e Ingenieros, amigos en su juventud, habían publicado juntos un periódico, La Montaña, de incendiaria prédica antioligárquica. Y Rojas, liberal muy siglo XIX, lograba ensamblar sus ideas, nada revolucionarias en el sentido europeo del término, con las de un nacionalismo de raigambre indianista. Henchido de unción, vaticinaba el mesianismo de esta América, destinada a engendrar una civilización y una cultura alimentadas con sus propios jugos. Latía esa unción casi mística en su cotazón de mediterráneo: nacido en Tucumán, ciudad de azahares, su estirpe arraigaba en la vecina Santiago del Estero, ambas del noroeste argentino. Y él, sin la tensa y silbante $s$ de los santiagueños, peculiaridad prosódica que acaso había perdido en los fisgadores medios estudiantiles de la capital y en sus andanzas por el Viejo Mundo, se asía afectivamente al fuerte tronco del padre, D. Absalón, varón de luces y de mando en su terruño reseco, cuyos algarrobos, "crespos de vainas doradas", iba a cantar el hijo poeta.

Muchos de nosotros veíamos a Rojas por la calle, en alguna redacción o en el teatro, en el recién inaugurado Colegio Nacional Belgrano, donde enseñaba literatura o, incidentalmente, en alguna comida de escritores. Frecuentaba aún los círculos literarios, de los que se alejó en los postrimeros lustros de vida. Además, diarios y revistas del país difundían su retrato: una cabeza de rasgos enérgicamente diseñados, como tallados a escoplo, tez broncínea, ojos de carbono, lacia melena aleonada, en la que -según dijo-le iban "pintando las canas" indiscretas hebras prematuras. Elástica la figura elegante, coronada por aludo y copudo sombrero de augur. Bien sabíamos que, en los trasfondos de su espíritu confesábase dominado por aquel demonio interior de los antiguos que, al parecer, le dictaba estrofas y romances. Pero a la inspiración irrefrenable, añadía Rojas la incesante lectura de todo lo nuestro, la pesquisa en bibliotecas y archivos apenas visitados por los escritores de su misma promoción, la reflexión sobre cuanto concernía a nuestra nacionalidad, para descubrir las verdaderas huellas de lo autóctono en las marchas ya cumplidas y para que no nos extraviáramos en las que debíamos reemprender. Le interesaba el pasado de la patria, pues quería interpretar nuestro presente - según él, más de factoría fenicia que de pueblo con orgánica unidad-y anhe- 
laba, sobre todo, señalarnos el mejor derrotero futuro. Había algo de arúspice en su prédica y mucho de sacerdote en su ademán. Mas tales exterioridades, bastante hieráticas, se desvanecían en la rueda amistosa, caldeada por Rojas de sonriente cordialidad, de bien dosificada gracia irónica, de raudalosa fluencia verbal. En lo último se asemejaba al cordobés Lugones, decidor beligerante, cuyas palabras le brotaban gatilladas en retahila sin fin. $\mathrm{Y}$ en esto se diferenciaban los dos del Ingenieros campechano, travieso, burlón, desconcertante, resuelto siempre a no darse importancia, de seguro para combatir el acartonamiento de muchos compatriotas que, sin tenerla, se la daban.

Del interés de Rojas por el pasado nacional quedaban evidentes muestras en sus libros de juventud y en la reedición de nuestros "clásicos", exhumados para su "Biblioteca Argentina". Uno de esos clásicos, Luis de Tejeda, gongorizante autor del Peregrino en Babilonia, fue descubierto por él cuando desempolvaba infolios en nuestros desorganizados archivos. $\mathrm{Y}$ esa "Biblioteca Argentina", a partir de 1915 , reimprimía textos que no estaban al alcance del lector medio y a cada uno de los textos, expurgados prolijamente, anteponía Rojas la necesaria advertencia o el prólogo esclarecedor o el estudio crítico aleccionante. Fueron, las suyas, ediciones insólitas en América para aquellas fechas. $\mathrm{Y}$ aunque entraron en competencia con las muy económicas que a la sazón lanzaba al mercado " $\mathrm{La}$ Cultura Argentina", bajo la dirección de Ingenieros, ha de convenirse en que las de Rojas tenían otra calidad por la cuidada revisión del material of recido al público. La amistad de ambos se enfrió momentáneamente, pues la empresa editorial común de que alguna vez habian hablado bifurcábase de improviso. El episodio suscitó breve polémica en las columnas de La Nación bonaerense. Mas quienes hemos tratado a uno y a otro y disponemos de suficiente ecuanimidad para juzgar ahora sus vidas dispares, no admitiríamos como de posible subsistencia la colaboración de los dos en tan útil iniciativa: muy claro vemos que el nervioso dinamismo a lo Sarmiento de Ingenieros, mal podía avenirse con la cautelosa labor de Rojas, digna de un aventajado discípulo de aquel Juan María Gutiérrez que tanto hizo por ordenarnos las letras de América. Permítase el aproximado símil retrospectivo dentro del elenco generacional de nuestros proscriptos heroicos, los de la época del tirano Rosas.

Lo cierto es que, volviendo al quehacer de nuestro autor, había diversos motivos, valederos y concordantes, para acordarle en 1917 amplio crédito como historiador de nuestra literatura. Databan de tiempo atrás El país de la selva, $L a$ restauración nacionalista y Blasón de plata. De 
I9I6, La argentinidad. Dirigia la "Biblioteca Argentina", en cuyos tomos -prefacios, textos y notas- se aquilataba su mucho saber y su curiosidad de bibliófilo y cómo los interrumpidos estudios jurídicos de la mocedad -aunque él les retaceara peso en la formación propia-le habían adiestrado para la valoración crítica de las pruebas en fechas y precedencias, en fuentes, influencias, contagios e imitaciones, en estilos de escuela y de época. A todo ello sumaba Rojas su interés por la historia de Hispanoamérica; su acucioso fervor por desentrañar de la tradición oral y escrita las auténticas voces telúricas de los Andes, de la zona norteña, del litoral atlántico, de la pampa, de nuestra olvidada Patagonia; el temblor religioso con que auscultaba el alma de América para saber qué le ocultaba esa América del pasado, qué confusa algarabía se escuchaba en la Argentina del presente y qué futuro aguardaba a la nacionalidad en la hermandad latina del continente, tema, este último, que desenvolvería luego doctrinariamente en Eurindid. Tenia entre manos para ajustarlos y repulirlos en su "Biblioteca", los textos de Moreno, Monteagudo y Gorriti, de Echeverría, Alberdi, Sarmiento y Hernández y nada esencial le faltaba para escribir la obra magna y documentar, ante connacionales y extraños, que muy legítimamente podía hablarse ya de una literatura argentina, negada por Mitre treinta años antes para la vastedad de la América hispana. Y esa obra magna de Rojas mereció en 1923 el Premio Nacional de Letras. Me place recordar que Ricardo Monner Sans formaba parte del Jurado que lo discernió. $\mathrm{Y}$ me place recordar, asimismo, que al año siguiente de morir mi padre y maestro, Rojas le dedicó una semblanza cordial y, creo, justiciera.

Hacia $19 x_{7}$ tal era, en apretada e incompleta síntesis, la labor de Rojas, publicista. Y su labor docente también avalaba la seguridad con que iba a afrontar la proyectada Historia. Desde 1912, en efecto, buscaba el modo de abrir picadas en la maraña de las letras argentinas. Al año siguiente, la Facultad lo designaba para ocupar la cátedra que acababa de incorporar a su plan regular de estudios. Proveía el cargo con quien, carente de título universitario, disponía de promisorios antecedentes como investigador $\mathrm{y}$ expositor didáctico. $\mathrm{Y}$ no es ocioso puntualizar de paso que, corridos dos decenios, la Universidad de Buenos Aires le otorgaría el doctorado "honoris causa".

2. Precisamente en I9I2, al presentar su "memoria" para optar a la cátedra, Rojas destacaba los elementos primordiales de nuestra literatura $o$, con alguna mayor extensión, de la literatura rioplatense. Abarcaba ésta 
cuatro siglos, y téngase en cuenta que durante ellos en las letras del Plata $y$, por supuesto en las de Hispanoamérica, se reflejaron los períodos correspondientes a los de España o, a veces, a los de Europa. Con respecto a los de España y a través de cuanto aparejaba para nuestros países la dependencia política, sirvió de trasmisor directo y poderoso el compartido idioma. Con respecto a los de Europa, el influjo ejercido por escritores extranjeros, preferentemente franceses. Notablemente menor el de los ingleses, italianos y alemanes. Se produjo así un clasicismo americano, harto desvaido, mientras los siglos de oro españoles of recieron temas de inspiración y recursos formales a los escritores de Indias. $Y$, a partir del XviI, se aclimató un neoclasicismo de trasplante, sujeto a muy rígida normativa. $Y$ ya desde 1830 el movimiento romántico liberó teóricamente de modelos y de reglas a Hispanoamérica. Teóricamente, digo, porque en Hispanoamérica se imitó a Hugo, Lamartine y Chateaubriand y a Goethe, Schiller y Byron. $Y$ en Hispanoamérica fueron también elogiosamente citados los remotos precursores ilustres, desde Shakespeare hasta Lope y Calderón. $Y$ en Hispanoamérica no tardó en repercutir el romanticismo español porque se leían los poemas de Espronceda, los artículos costumbristas de Larra y, luego, la torrencial obra en verso de Zorrilla. Pero Hispanoamérica, por aplicación de los principios románticos y-nótese bien- por natural irradiación de los movimientos de emancipación política, logró dar peculiar entonación a algunas de sus mejores obras: valga como ejemplo confirmatorio nuestro Facundo. Y es fácil comprobar que el romanticismo de Esteban Echeverría fue sincrónico del español, apenas anticipado éste en polémicas locales, en ocasionales traducciones del inglés y el alemán, acogidas por periódicos - El Europeo, de Barcelona, entre ellos-con anterioridad a 1830 . Puede, pues, afirmarse que el romanticismo rioplatense no recibió del español su impulso inicial.

Medio siglo después, Hispanoamérica se adelantaría a España en la renovación de verso y prosa, circunstancia anotada por Rojas en su Historia y expuesta con clara argumentación por Pedro Henríquez Ureña desde la cátedra y en estudios y libros: según decía el gran maestro dominicano, eran esos americanos de distintas latitudes, desde Martí y Gutiérrez Nájera hasta Casal, Silva y Dario, los que empezaban a escribir "de otra manera" entre 1882 y 1896 . A poco, la Antologîa de Federico de Onís ilustraría tal aserto. Mas esa "otra manera" provenía de contaminaciones de muy diferentes orígenes: ya de Poe y su descendencia francesa; ya de Heine y sus traductores españoles y americanos; ya del parnaso y el simbolismo que París exportaba en todas direcciones; ya de autores que en Italia o 
Portugal o Estados Unidos manifestaban lo suyo con muy insólita experésividad, como aquellos Raros que Rubén Darío divulgó entre nosotros del 93 al 96. Si Hispanoamérica seguía viviendo de préstamos concertados en el mercado internacional de las letras, el del modernismo aparecía bajo signo diferenciador, pues combinaba químicamente ingredientes de retortas diversas y los vertía en alambiques de fabricación propia. Mas, a la postre ¿sólo restaba esta veta finisecular para la creación genuina en la América hispana y, dentro de ella, en la cuenca platense?...

He reseñado abreviadamente la evolución de nuestras letras a fin de recalcar que, en el bienio 1912-13, Rojas se planteaba el complejo problema de distinguir en ellas las características primordiales, exteriorizadoras de su más recóndita esencia. $\mathrm{Y}$ para desentrañarlas recurría en parte a las indagaciones hechas por varios predecesores $y$, fundamentalmente, a sus indagaciones personales. Era menester examinar todo el material reunido y ver si aun esa literatura de reflejo o de trasplante se revestía de colores y matices nacionales, si, independientemente de ella, había en la literatura rioplatense una porción de germinación autóctona y si en esta germinación podía rastrearse, dentro de esa literatura, "la ley oculta del proceso histórico y la pragmasis de nuestra propia estética". Imbuido Rojas del concepto que el historicismo del siglo XIX impuso a la crítica literaria, quería ver "la literatura argentina como una función de la sociedad argentina", porque cualquier literatura trasparenta "la conciencia colectiva de un pueblo". Y con este enfoque que cien años antes Mme. de Staël no hubiera desechado, Rojas se aprestaba en I9I 7 a escribir un "ensayo filosófico sobre la evolución de la cultura en el Plata".

Los rumbos o perspectivas para seguir el desarrollo de esa literatura recibida de fuera podían, sucesivamente, apuntar hacia el clasicismo y el neoclasicismo, hacia el romanticismo, hacia el modernismo. Si se hubiera embretado Rojas en las denominaciones usuales, su enfoque habría mantenido la terminología empleada por los manuales destinados a estudiar la literatura de habla española entre los siglos XVI y XIX. Pero logró contemplar ese proceso temporal con lente americano y, más cerradamente, rioplatense. De ahí que, sin borrar caprichosamente la división externa en períodos históricos, designara uno de esos rumbos con el título de Los coloniales. Sin borrar, repito, la división, pero corrigiendo la cronología, pues los fenómenos literarios, internos en la vida social de un pueblo, no acomodan con estrictez sus variaciones a las vicisitudes de índole política. ¿Cómo ignorar que nuestros últimos escritores "colonia- 
les", de neta filiación neoclásica, llegan hasta Juan Cruz Varela, poeta y dramaturgo desaparecido en 1839 , suerte de Quintana argentino que dio destellos literarios al ilustrado régimen rivadaviano?

Vistas así las letras nacionales que se ajustaban a los patrones del clasicismo y del neoclasicismo, arrancaban de la conquista española, florecían durante la era virreinal y se prolongaban en la época revolucionaria $y$, aún, postrevolucionaria, cuando ya se había afianzado la emancipación política rioplatense. Era, pues, la de los coloniales una dilatada etapa de literatura hispana en territorio americano.

Consistió el segundo acierto de Rojas en no utilizar el calificativo de "romanticismo" para otro de sus rumbos o perspectivas. En efecto: aunque según la repetida fórmula huguiana, "el romanticismo no es sino el liberalismo en literatura" y aunque muchos de los románticos europeos y americanos se cobijaron bajo los lemas de la Revolución Francesa, no fue necesario que todos se alistaran como combatientes en pro de la libertad de su patria, subyugada por un tirano. Aquí, sí lo fue: Echeverría, Juan María Gutiérrez, Alberdi, Sarmiento, Cané padre, Vicente Fidel López, Mármol, Mitre y algunos más nacieron entre 1805 y I82I y, desde el destierro, lucharon contra Rosas con las armas a su alcance. "Mientras el dolor de la patria - decía Rojas- les unió en el destierro, todos formaron una sola familia. Pocos sucesos hay tan hermosos como la emigración del tiempo de Rosas, ni tan eficaces como enseñanza para edificar a la juventud de las aulas en el culto de la patria, de la belleza y de la libertad".

Estas circunstancias nacionales hicieron que la cultura, asfixiada en la Argentina, buscara oxigenarse en otras naciones - preferentemente el Uruguay y Chile-y por eso denomina Rojas "período de la proscripción y no de la tiranía" al que media políticamente entre 1838 y 1852 y que, literariamente, se extiende desde 1830 , fecha del retorno de Echeverría al país, hasta 1880 , fecha de la capitalización de Buenos Aires y cifra redonda para situar a la generación que, promediando los treinta años, se constituía con los hijos de aquellos padres. Hijos del espíritu todos. Y, algunos, hijos de la sangre: Miguel Cané (hijo), Lucio Vicente López, Bartolito Mitre, nacidos en el exilio.

Llamarlos románticos hubiera sido reducir su significación dentro de nuestro ambiente literario, pese a que entre I 838 y I 852 Echeverría escribió Los consuelos y las Rimas, Sarmiento el Facundo y Mármol sus Cantos del Peregrino. Llamarlos liberales hubiera sido reducir también su signifi- 
cación, pese a que, en el mismo lapso, Echeverría escribió su Dogma socialista y Sarmiento aquel libro extraño y polifacético y Alberdi las Bases para nuestra Constitución del 53. Toda esta producción y la restante que aquí omito, fue de muy diversificada urdimbre intelectual y apareció fuera del país: literatura de los proscriptos porque en la proscripción se asiló la cultura argentina. $Y$ esa literatura, cargada de liberalismo y teñida de romanticismo, se localizó en órbita geográfica extranacional y, cuando combatió al tirano, se encrespó de denuestos en la prosa periodística de los desterrados, en los versos flojones de Echeverría y en los hirvientes y agoreros de Mármol. Las estrofas de éste recordaban, ya las de aquel Espronceda de la "Canción del pirata", y a las muy polimétricas de aquel Zorrilla de "La azucena silvestre". Como los cuadros costumbristas de nuestros proscriptos, sobre todo los de Alberdi, recordaban los de aquel Fígaro español, cuya prosa se remedaba por entonces en tierras platenses.

Otro acierto de Rojas - fácil acierto en este caso-fue el de no agrupar a los escritores del 80 y sus seguidores bajo el rótulo de "modernistas", que hubiera sido notoriamente inapropiado para ellos, a pesar de que del modernismo recibieron varios, alrededor del 900 , cierta superficial influencia. Sin embargo, no fue el modernismo, ni podía serlo dos decenios antes, su denominador común.

Los del 80 , de vida más regalada que la de sus padres, cultivaron la novela, el cuento, el ensayo y se aficionaron a coleccionar buena parte de su producción en libros de la más surtida miscelánea. Admiraron a los franceses, de Taine a Renan y de Balzac y Flaubert a Zola y France, a los ingleses, en particular a Dickens, y leyeron de tanto en tanto a los italianos. Muy de paso a los españoles, de Galdós y Valera a Alas y Blasco Ibáñez. Varios de ellos afinaron el gusto literario en su frecuente rodar de viajeros. Algunos ocuparon cargos diplomáticos. Todos revelaron interesarse por el ancho mundo de la cultura, acaso porque el mundo empezaba ya geográficamente a achicarse, y Buenos Aires a dejar de ser, municipalmente, La gran aldea de años atrás, que Lucio V. López nos describía el 84 .

Prevalecía a la sazón el positivismo, aprendido en Comte y en Spencer. Su proyección literaria originaba la novela realista, mechada de costumbrismo local, $\mathbf{o}$, a veces, la novela de visibles toques naturalistas. Quizá Rojas se excede al sentenciar que Zola tuvo aquí lectores, pero no "verdaderos prosélitos", pues Sicardi, Cambacères, Martel, Podestá, García Mérou y aún el ya citado Lucio V. López adoptaron procedimientos de compo- 
sición, recursos de técnica y hasta modalidades de estilo procedentes del naturalismo francés. Algo semejante aconteció a principios de siglo en el teatro con Florencio Sánchez y Roberto J. Payró. Bastantes menos con Gregorio de Laferrère. Los poetas, en cambio, of recieron un cuadro muy matizado en las diferentes promociones aparecidas alrededor del $80 \mathrm{y}$ en los lustros siguientes: Andrade y Ricardo Gutiérrez, Guido Spano y Rafael Obligado, "Almafuerte", Leopoldo Díaz, Lugones, Carriego, Banchs, etc. Nuestras antologías prueban cómo en el 80 resonaban todavía ecos románticos en la lírica argentina, algunos de timbre muy nacional, y cómo, a poco, resonaría el dispar vozarrón de "Almafuerte", la modulada voz de Díaz, parnasiano de inconmovible fe, el multísono registro de Lugones, la voz velada de tristeza en las notas suburbanas de Carriego y la que se ahilaba de pureza expresiva en las estrofas de Banchs.

Bien se colige que no todos esos escritores, y los demás que aquí omito, podían calificarse de modernistas. Rojas eludía hablar de varios de ellos porque aún vivían y prefería elegir para ese conjunto un cómodo "título de simple valor cronológico": los modernos. Pero si quería enjuiciar serenamente cuanto hicieron en distintos géneros literarios los desaparecidos, era menester situarse a mayor distancia, y Rojas, de 1917 a 1922, estaba demasiado cerca de figuras correspondientes a ese pasado inmediato, varias pervivientes. De ahí que Los modernos, por "razón de materia" según suele decirse en derecho, no of rezca solidez equivalente a la de los otros tomos de su Historia.

3. Se había iniciado ésta con Los gatchescos, filón literario ríoplatense que el profesor iba a estudiar en el curso de I9r3. Su contenido total, desde los balbuceos del folklore hasta el poema de Hernández - culminación de los temas gauchescos que luego trasmigran a otros géneros-, brindaba al investigador las posibilidades de un minucioso rastreo; al ordenador de sus resultados, la satisfacción de organizar esa masa informe que constituía el acervo casi exclusivo de ambas orillas del Plata; al teorizador de nuestra integración nacional, la oportunidad de observar, sucesivamente, los aportes con que el indio, el conquistador y el gaucho contribuían a enriquecer aquel filón literario. "Una literatura nacional - decía Rojas-es fruto de inteligencias individuales, pero éstas son actividades de la conciencia colectiva de un pueblo, cuyos órganos históricos son el territorio, la raza, el idioma, la tradición. La tónica resultante de esos cuatro elementos se traduce en un modo de comprender, de sentir y de practicar la vida, o sea en el alma de la nación, cuyo documento es la 
literatura". De indio, conquistador y gaucho descendian los criollos de hoy. Pero, a partir del 80, otros argentinos descendían de inmigrantes aquí radicados. Estos nuevos injertos étnicos, los de la nutrida segunda colonización, fueron considerados por Rojas en el tomo de Los modernos, mas, empeñado en forjar una doctrina indianista, exageró la subsistente pujanza de aquellos cuatro elementos, especialmente el terrígeno. Nada fácil pronunciarse sobre la plena exactitud de tan ambiciosa lucubración.

Aceptable en cambio que, parejamente a cuanto ocurre en otros pueblos americanos, sean en la Argentina poderosos factores de homogeneización los cuatro elementos antedichos. Estos factores influyen en el inmigrante y su progenie, pues excluidos algunos europeos y asiáticos que nos llegan de determinados países, los demás se funden a poco con los nativos de América. El territorio hace suyos a casi todos; los inmigrantes pierden paulatinamente las costumbres heredadas y las características originarias, psíquicas y mentales, y amalgaman sus razas diversas con la nuestra, si es que de razas puede hablarse todavía en este enorme crisol humano de América; sustituyen los respectivos idiomas por el español más o menos regional que aquí utilizamos y algunos de esos inmigrantes entran en contacto con la tradición del pueblo donde viven. Sus hijos y nietos se sienten uruguayos o chilenos o argentinos. $Y$ a veces los mismos trasplantados a nuestro suelo, declaran su condición de españoles o italianos "acriollados". Dicho esto, preguntémonos si en vasta escala puede lograrse esa recuperación de lo fidedignamente autóctono, esa suerte de "restauración nacionalista" por medio de una educación que ha de abastecerse en nuestras secretas fuerzas telúricas. $Y$ preguntémonos si puede asegurarse que la doctrina indianista de Rojas, aun reducida a su prístino sentido geográfico, se hará carne en tan heterogénea masa inmigratoria o, siquiera, en cuantos de ella nacen. Cabe dudatlo.

En escala menor, sí puede hablarse de criollismo y no de indianismo. Porque lo menos, el criollismo, es una de las formas de la adaptación, incoercible ley biológica. Pero el criollismo, que es además un fenómeno social de contagio, depende en buena medida de la altura mental de cada remesa aluviónica, de la acogida que a ésta dispensen el régimen político y las leyes del país, de los establecimientos públicos donde se eduquen sus hijos, de la posibilidad de levantar aquí su tienda y convertir pronto su tienda de nómades en casa estable con calor de hogar.

La literatura ríoplatense, y por extensión la americana, han encarado estos temas con muy rico repertorio de asuntos: para escoger sólo un ejemplo de ambas orillas del Plata, rememórese La gringa de Florencio 
Sánchez. Y si tal comprobación se desprende de obras que buscan su trama en la cotidiana realidad de nuestros pueblos, la convalidan asimismo obras de bien distinto género. Entre ellas, esta Historia de Rojas, donde - con nomenclatura muy valedera- se estudian, no los clásicos y neoclásicos, no los románticos, no los modernistas y sí los coloniales, los proscriptos y los modernos de nuestra Argentina. De seguro, porque siguen teniendo validez aquellos factores condicionantes de las letras que Taine expuso en su Introducción a la literatura inglesa y aplicó en su Filosofía del arte. No los desdeñó Rojas en la concepción de su plan, según se infiere del conjunto. Como no desdeñó los factores individualizantes o biográficos, que la crítica de nuestro siglo aprendió en Sainte-Beuve, o la indagación de designios estéticos, ya conscientes o inconscientes, visibles u ocultos en las obras de creación, que Menéndez y Pelayo enseñó a descubrir en la producción escrita para mejor conocer el peculiar desarrollo de una literatura.

Mérito de Rojas fue el de clasificar nuestro material gauchesco para mostrarnos cómo de las minúsculas semillas del folklore ríoplatense brotaban, tiempo más tarde, floraciones épicas, líricas y hasta dramáticas; cómo las de vieja germinación conservaban savia indígena, incluso en la hibridación bilingüe; cómo ese arte popular pedía el acompañamiento musical de la guitarra y cómo la métrica de arte menor -octo, hepta, penta y tetrasílabos - acompasaba los cantos del gaucho. Aquel gaucho cantor, abocetado por Sarmiento en Facundo, es el payador que Rojas nos presenta desde antes del xIx para exhibírnoslo como distante hermano de aedos y rápsodas, de juglares y trovadores. Por eso el nombre de "escuela payadoresca" conviene a la intención definidora del crítico y por eso destaca Rojas en Martin Fierro - con sus descripciones y retratos, con sus soliloquios, diálogos y payadas- la más acabada expresión de nuestra literatura gauchesca.

A fines del siglo xrx, y antes que Rojas, varios escritores españoles habían señalado la legitimidad de la rama gauchesca en el añoso tronco del castellano. $Y$ varios españoles, americanos y argentinos habían celebrado la buena cepa de nuestro poema máximo. Sin embargo, la valoración del Martin Fierro desde el punto de vista social y como exponente de nuestra literatura patria y, más ampliamente, desde el punto de vista de su importancia estética en el panorama de las letras americanas, cs galardón de nuestro siglo. Data de I9I3 esa valoración, es decir, del primer curso universitario de Rojas, de las conferencias que pronunció Lugones, luego publicadas bajo el título de El payador (1916), y de la inquisición que 
aquel año abrieron Roberto F. Giusti y Alfredo A. Bianchi en la revista Nosotros.

La tesis sustentada en el citado curso cimentaba la doctrina total de sus Gaucbescos y coronaba los capítulos dedicados al Martín Fierro. Partía Rojas del personaje central, empeñado en doble lucha: "a su frente, con la naturaleza y el indio; a su espalda, con la organización nacional rudimentaria u hostil a las costumbres ya anacrónicas del gaucho". "Tal es la gesta-proseguía-que Martín Fierro ha pintado, constituyendo por consiguiente dicho poema, como expresión de aquel proceso social, un verdadero poema épico, ligado al ciclo heroico de Ercilla por la materia histórica y nacido de nuestros propios orígenes nacionales por su tema, sus protagonistas, su ambiente, su idioma, sus ideales". Y conviniendo en que "el gusto académico se inclinará a rechazar esa filiación" porque hay distingos fundamentales que hacer entre La Araucana y Martín Fierro, afirmaba la imposibilidad de encuadrar nuestro poema en "las categorías de la retórica tradicional... acaso porque nuestro cantar gauchesco es cualquier otra cosa menos una obra de retórica". Consecuentemente, era menester orientarse por "el secreto vital de una epopeya", ya que éste "reside en su identidad con el espíritu de una raza; su radicación en la tierra que ha de servir de asiento a una progenie histórica; su modelación sobre el arquetipo fundador de una determinada nacionalidad". Y, después de repasar la añeja teoría de la epopeya y de parangonar los poemas que la literatura comparada señala como paradigmas hasta la época renacentista, concluía Rojas: "Dentro de los géneros clásicos, a lo que más se parece el Martin Fierro es a una epopeya, sin ser tampoco una epopeya en el sentido tradicional de esa palabra". De más está puntualizar que el criterio de Rojas - menos asertivo de lo que en un principio parecíano fue compartido por muchos y así lo documentan, entre otras páginas, las de la inquisición de Nosotros.

Si epicidad equivale, en suma, a "narración", la epicidad del Martín Fierro no estaba ni está en tela de juicio. El problema debía centrarse, no en el género narrativo de la obra, sino en su especie. ¿Epopeya?... Han trascurrido más de cuarenta años. Durante ellos el poema de Hernández ha suscitado la atención cuidadosa de varios escritores argentinos y extranjeros. De él en edición crítica, y de su lengua en particular, of reció dos volúmenes la paciente labor filológica de Eleuterio F. Tiscornia. Sobre los manuscritos de Hernández trabajó minuciosamente Carlos Alberto Leumann. Varios escritores de más recientes promociones han sopesado de nuevo la jerarquía del poema en la literatura ríoplatense y la signifi. 
cación humana del gaucho en nuestra existencia nacional. $\mathrm{Y}$ transcurridos esos años, casi medio siglo, aquel problema atinente a la especie del poema nos preocupa menos que a la generación de Lugones y Rojas. Tal vez porque, sobre lo argüido por ambos, poco pueda agregarse ahora, o porque ahora ha cambiado el punto de mira para enfocar la obra o porque el criterio de valoración estética gradúase ahora de distinta manera.

También se debe a Rojas el señalamiento de las tres etapas capitales, ya indicadas, en que puede dividirse la literatura gauchesca. Me parece, sin embargo, que entre la primera, de germinación oral, y la segunda, abarcadora del ciclo de poemas extensos - los de Echeverría, Ascasubi, del Campo, Hernández y Rafael Obligado-, sería necesario intercalar otra que delineara la trayectoria recorrida desde el folklore de los primitivos hasta la fijación escrita de sus temas característicos. Esa etapa intermedia ha de situarse de fines del xviII a los primeros tres decenios del xIX. Pero bien advierto que esta observación marginal requetiría mayor desarrollo y éste no cabe aquí.

4. Antes de publicarse la Historia de Rojas no contábamos con ninguna que siquiera esbozara el panorama total de nuestros cuatro siglos de literatura. De años atrás databa el manual, superficial e incompleto, escrito por Enrique García Velloso. Y años después de publicada la Historia aparecieron varios más para estudiantes de segunda enseñanza, cuyos autores se beneficiaron de la ordenación didáctica dada por Rojas al correspondiente material. ${ }^{1}$ Otro más reciente, de la Editorial Labor, poco agregó a lo ya conocido. De esa bibliografía meramente escolar han de apartarse los cuatro tomos que sobre Las ideas estéticas en la literatura argentina se imprimieron entre I92 I y I926, escritos por el entonces joven profesor Jorge Max Rohde, pues fue obra concienzudamente hecha, en la que se estudiaban separadamente los géneros literarios: lírica, teatro, novela $y$ crítica.

Cuando Rojas dio a las prensas el primer tomo, Los gaucbescos ( 1917 ), decía en el prefacio: "He vacilado largo tiempo antes de decidirme a publicar esta obra; pero cuanto más retardaba su aparición para mejorarla, iba creciendo en mí la certidumbre de sus imperfecciones". Y

1 Excluyo, por supuesto, los de aquellos escribas que, durante la dictadura sufrida por la República (1943-55), improvisaron algunos manuales para ganar pesos y satisfacer la megalomanía de la pareja gobernante. En uno de esos libros se colocaba $L a$ razón de mi vida, obra que firmaba la esposa del dictador, por sobre la producción de Sarmiento... 
admitía que era "labor condenada a errar en menudos detalles o a envejecer en el continuo avance de las investigaciones". Razonable y prudente tal advertencia, pues ligeras fallas de fechas y de títulos de menor importancia, de datos bibliográficos o de reseña de argumentos pueden, sí, pesquisarse en la primera edición, varias subsistentes en las posteriores. Pero la obra no ha sido sustituida por ninguna de equiparable altura ni de equiparable profundidad en los cuarenta años que nos distancian de I9r7. $Y$ la que, de carácter colectivo, se anuncia desde hace diez bajo la dirección de Rafael Alberto Arrieta, no ha salido aún a luz. Todo ello prueba, muy objetivamente, el considerable esfuerzo individual de Rojas.

Indudable es, asimismo, que la Historia ha envejecido por "el continuo avance de las investigaciones". Mucho se ha hecho del 23 al 46 y algo del 47 al 57 para esclarecer la significación de varios autores, para corregir pormenores a ellos atinentes o para proseguir la indagación de puntos que conciernen a diversas piezas de la bibliografía nacional. Podría ejemplificarse el aserto con la escueta mención de estudios relativos a la producción de Manuel de Lavardén, Juan Cruz Varela, Esteban Echeverría, Juan María Gutiérrez, Juan B. Alberdi, Domingo F. Sarmiento, José Mármol, Bartolomé Mitre, Hilario Ascasubi, Estanislao del Campo, José Hernández, Olegario V. Andrade, Carlos Guido Spano, Lucio V. Mansilla, Eduardo Wilde, Miguel Cané (hijo), Lucio V. López, Eugenio Cambacéres, Julián Martel, etc. $Y$ otro tanto podría decirse acerca de las sucesivas promociones literarias y de su solapamiento temporal, puntos mejor estudiados hoy en función de los conceptos disímiles de "coetaneidad" y "contemporaneidad" y de los llamados factores "aglutinantes" o "nivelantes" en la natural formación de las generaciones argentinas. Y otro tanto podría afirmarse de la repercusión del modernismo en nuestras letras durante el postrer decenio del siglo pasado y el primero del presente.

Estas observaciones, y algunas más que sería fácil apuntar de paso, en nada desmerecen la ingente tarea llevada a cabo por Ricardo Rojas. Pero si bien la arquitectura general de su Historia prueba palmariamente la feliz delineación de los cuatro rumbos o perspectivas - gauchescos, coloniales, proscriptos y modernos-, no parece surgir comprobada una "teoria" indianista de nuestras letras. Sí una gravitación espãcial o geográfica, sólo prevaleciente en el filón de los gauchescos y que ejerce muy intermitente influencia en el acervo literario de los coloniales, de los proscriptos $\mathrm{y}$ de los modernos.

Aparte de la seriedad en el sistema de investigación y del rigor en el método de trabajo, tampoco parece desprenderse de las ideas articuladas 
por Rojas una "escuela" de rasgos diferenciadores. Salvo que por escuela se entienda un sistema de investigación y un método de trabajo poco utilizados antes entre nosotros. En este doble menester, el magisterio de Rojas fue de fecundos resultados, pues sirvió para combatir, siquiera en alguna proporción, ciertas endemias muy criollas: profusa y confusa divagación seudoestética o seudoscciológica, presuntuosa repetición o desfachatada apropiación de hallazgos ajenos, osada garrulería de los grafómanos.

No se equivacó al decir él en ror 2 que recibía "una cátedra sin tradición y una enseñanza sin bibliografía". Y no se equivocaría hoy quien dijera que Rojas satisfizo ambas necesidades: su cátedra tiene una tradición, que yo, en la medida de mis fuerzas, traté de no deslucir del todo en 1944 y en 1956 al encomendárseme interinamente. Esa tradición se jalona, año tras año, de I9I3 a 1946, fecha en que Rojas renuncia a ella. De ella no se hace cargo en 1955 al ser repuesto, caída la dictadura. $Y$ aquella tradición se vigoriza con los veintinueve tomos de su "Biblioteca Argentina", editados durante el lapso I9I5-28 y con las tareas realizadas en el Instituto de Literatura Argentina, que funda en 1922 y dirige hasta 1946. Las numerosas publicaciones del Instituto atañederas a los orígenes de la novela argentina y a los del teatro nacional, los opúsculos sobre historia de nuestro teatro y la serie de estudios críticos sobre temas de diversa índole, los muchos y útiles tomos ordenadores de nuestro folklore, reúnen en conjunto una organizada información para cuantos quieran especializarse en literatura argentina. Tan extraordinaria faena fue cumplida tesoneramente por Rojas y nadie, ni antes ni después de él, ha podido ser su émulo. Conjeturo que la posteridad, acallados resquemores y envidias, habrá de sentenciarlo así.

Las muchas páginas de su Historia (1917-22), que él apenas retocó para ediciones posteriores - algunas con índices onomásticos y de materias a fin de facilitar su compulsa- están escritas digna y amenamente y atraen a cualquier lector de medianas letras. Hay en esas páginas, a veces, cierta tendencia a la reiteración machacona, quizá debido a la intención docente de la obra. Hay, ocasionalmente, deslices sintácticos. Hay, a menudo, demasiada simetría en la marcha un tanto marcial de su prosa. Hay en ella, aquí o allá, muy audible tono oratorio, algún empaque tribunicio que le sale muy de lo hondo porque este escritor, de pluma suelta y flexible, llevaba dentro de sí a un experto conferenciante, cuyo caudaloso don verbal se desbordaba en los párrafos recios o armoniosos que emitia su bien impostada voz y que reforzaba con su gesto y rubricaba con 
su ademán. Y si dichas virtudes lo dotaban de admirable poder suasorio en la cátedra, su estilo tesentíase de cierto calculado engolamiento y de cierta propensión al uso desmedido de referencias que, en primera persona, le concernían. Defectos minúsculos a la verdad si, colocados en la columna del debe, figuran en su haber tan elevadas cifras: comprometen éstas la gratitud de todos los argentinos cultos.

José María Monner SANs, Universidad de Buenos Aires. 